\title{
E-shopping: An Analysis of the Uses and Gratifications Theory
}

\author{
Weng Marc $\operatorname{Lim}^{1} \&$ Ding Hooi Ting ${ }^{1}$ \\ ${ }^{1}$ Monash University, Malaysia \\ Correspondence 1: Weng Marc Lim, School of Business, Monash University, Malaysia. E-mail: \\ lim.weng.marc@monash.edu \\ Correspondence 2: Ding Hooi Ting, School of Business, Monash University, Malaysia. E-mail: \\ ting.ding.hooi@monash.edu
}

Received: February 13, 2012 Accepted: February 28, 2012 Online Published: May 1, 2012

doi:10.5539/mas.v6n5p48 URL: http://dx.doi.org/10.5539/mas.v6n5p48

\begin{abstract}
The Internet has experienced an exponential growth in the number of users and has created enormous increases in its marketing and communication applications during a considerably short period of time. Although both scholars and practitioners have jointly acknowledged the capabilities of the Internet as a marketing tool that offers great potentials and advantages, there remains a scarcity of knowledge pertaining to the motivations for using the Internet and associated online consumer behaviours in more web-specific scenarios. The uses and gratifications theory (U\&G) provides a theoretical grounding and an avenue to further understand consumers' attitude and intention of using the Internet as a shopping channel from a media perspective. While most of the studies done on the U\&G in the Internet are situated in American and European contexts, this paper considers the U\&G structure of online shoppers in the Asian context (more specifically, in Malaysia). More specifically, this study attempts to shed some light on how consumers form their attitude and online shopping intention based on the uses and gratifications structure to the existing literature and managerial implications for entrepreneurs and marketers of electronic businesses on how best to serve and attract consumers to shop online via the management of online shopping technologies.
\end{abstract}

Keywords: E-shopping, uses and gratifications theory, entertainment gratification, informativeness gratification, web irritation, attitude towards online shopping, intention to shop online

\section{Introduction}

Using the Internet is an activity that an increasing number of people are participating in (Siekpe \& Kamssu, 2005). By November 2011, there were over two billion Internet users worldwide (Internet World Stats, 2011). Notably, the number of Internet users grew by 580 percent when compared with the figure in 2000 (Central Intelligence Agency, 2011; Internet World Stats, 2011).

There is little doubt that the Internet has experienced an exponential growth in the number of users and has created enormous increases in its marketing and communication applications during a considerably short period of time (Ko et al., 2005). It is acknowledge that the Internet is being used for varying reasons, including as source of information, a method of communication, a marketplace medium, and a social system (Maignan \& Lukas, 1997). Concurrently, as browsing and interacting with the Web continuously improves, the Internet has become a viable channel for marketers and an increasing number of businesses see it to be indispensable in order to remain competitive in the modern day globalized economy (Siekpe \& Kamssu, 2005).

According to Jere and Davis (2011), the Internet has distinctive features that set it apart from traditional media. It is interactive (Rafaeli \& Sudweeks, 1997) and it has global reach (Berthon et al., 1996). Berthon et al. (1996) further added that establishing a presence on the Internet consumes relatively lesser amount of resources that allows for more sophisticated audience segmentation. In turn, these characteristics have turned the Internet into a 'virtual marketplace' where interactive tools can be used to enable businesses with online presence to build and strengthen relationships with their target customers (Ko et al., 2005). In other words, the existence of the virtual marketplace facilitates the interaction between consumers with a wide array of product choices in a nonlinear fashion.

Although much of the current literature acknowledges the capabilities of the Internet as a marketing tool or medium that offers great potentials and advantages (Cook \& Coupey, 1998), there remains a scarcity of knowledge pertaining to the motivations for using the Internet and associated online consumer behaviours in 
more web-specific scenarios (Luo, 2002). Some existing studies (Korgaonkar \& Wolin, 1999; Papacharissi \& Rubin, 2000) have identified Internet usage motivations while others have developed structural models based on Internet users' online experiences (Novak et al., 2000; Luo, 2002). Entrepreneurs and practitioners of online businesses, however, remain nostalgic for more empirical context-specific insights with regards to the online business environment (Ellison, 2010). More specifically, only a crude understanding exists about the motivations of consumers to shop online from online shopping sites as knowledge on these motivations focusing from the role of interactivity remains in scarcity.

The uses and gratifications theory ( $U$ \& $G$ ) is a time-honoured media use theory, helpful for understanding consumer motivations for media use, and has been applied to scenarios ranging from radio to television, cable TV, and now the Internet (Roy, 2008). With its emphasis on active media use and its ability to span both mass and interpersonal communication, uses and gratifications is regarded as a natural paradigm for understanding the use of the Internet (Morris \& Ogan, 1996). While the utility of the Internet as a powerful telecommunications medium is compelling, the Internet is far more than just a conglomeration of websites positioned to sell goods (Grover \& Pradipjumar, 1999; Palmer \& Griffith, 1998). Notably, the Internet is a medium with rich media (e.g. advance technologies can be applied upon web pages such as video streaming, interactive features and etc) and thereby becomes a powerful tool to attract and retain the interest of site visitors (Rosenkrans, 2009). As consumers are now showered with a luxury of an increasing number of online shopping sites to shop from, getting to the heart of these consumers will become more important for entrepreneurs, marketers, and web developers of online shopping sites. Hence, given the underlying necessity and upward challenge of attracting consumers to support and purchase online market offerings, the understanding of why consumers choose to use the Internet to shop has great relevance in the commercial model of online business (Novak et al., 2000; Weinberg, 2000).

Despite the application of the $U$ \& $G$ theory to the case of the Internet, most studies seem to be conducted either in the American or European context. Notably, a dark area prevails in the body of knowledge for an understanding on the application of this theory among Asian Internet users. Moreover, the application of this theory into web-specific scenarios remains scarce. Thus, this paper tries to address this gap by applying the U\&G structure into the investigation of the motivations for consumers to shop online in the Asian context (more specifically, in Malaysia). The application of the $U$ \& $G$ theory provides a theoretical grounding and an avenue to further understand consumers' attitude and intention of using the Internet as a shopping channel from a media perspective. The knowledge this study generates will contribute in two ways: in terms of theory, this study provides an empirical understanding on the influence of the uses and gratifications structure in Malaysian consumers towards online shopping; and in terms of practice, this study presents strategic implications and directions for the development of online shopping in Malaysia.

\section{Literature Review}

\subsection{Uses and Gratifications Theory $(U \& G)$}

The $U$ \& $G$ theory originated from the functionalist perspective on mass media communication and was first developed in research on the effectiveness of the radio medium in the 1940s (Luo, 2002). Various research using this theory have found it fruitful in understanding consumers' motivations and concerns for using various media such as radio, TV and electronic bulletins (Eighmey \& McCord, 1998). In particular, this theory seeks to recognise the important role of the individual in the use of mass media by focusing on what people do with mass media (Katz, 1959; Klapper, 1960). Katz et al. (1974) have put forward the basic assumptions of the U \& G approach. First, the audience is active and thus the use of mass media is goal directed. Second, the audience makes motivated choices, based on previous experience with the media. Third, media selection and use are purposive and motivated and people take the initiative in selecting and using communication vehicles to satisfy felt needs and desires. Fourth, the media compete with other sources of need satisfaction. Finally, value judgements about the cultural significance of mass communication should be suspended while audience orientations are explored on their own terms. Therefore, based on the mentioned assumptions, Rubin (1994) suggests that the primary objective of the $U \& G$ theory is to explain and understand the psychological needs which shape people's reason for using the media and the reasons which motivate them to engage in certain media use behaviours for gratifications that fulfil their inherent needs, including the identification of the positive and negative consequences of individual media use.

Past researchers have tried to identify the psychological and behavioural aspect of Internet users to recognize the underlying motivations for Internet usage. According to Kaye and Johnson (2001), users of the Web are more actively involved and engaged in using the Internet because of its interactivity. Since one of the key strengths 
attributed to the Internet is its interactivity and since an active audience is the core concept of the $U$ \& G theory, the $U$ \& $G$ theory is regarded as the most effective theoretical basis for studying this medium (Hanjun, 2002). This is supported by Ruggiero (2000) as the rapid growth of the Internet has strengthened the potency of the U \& $\mathrm{G}$ theory because this medium requires a higher level of interactivity from its users in comparison with other traditional media. Indeed, past research has also suggested that the Internet is 'intentionally consumed' as audiences must make purposive choices about which site to visit (Rayburn, 1996).

Table 1. Selected media uses and gratifications typologies 1983-2011

\begin{tabular}{|c|c|c|}
\hline Author(s) and years & Medium & Uses and gratifications typologies \\
\hline Rubin (1983) & Television & $\begin{array}{l}\text { Entertainment, pass time, escape, information, } \\
\text { companionship }\end{array}$ \\
\hline Payne et al. (1998) & Magazine & Diversion, surveillance, interaction \\
\hline O’Keefe and Sulanowski (1995) & Telephone & $\begin{array}{l}\text { Entertainment, socialability, acquisition, time } \\
\text { management }\end{array}$ \\
\hline Kaye (1998) & The Internet & $\begin{array}{l}\text { Entertainment, pass time, escape, social interaction, } \\
\text { information, website preference }\end{array}$ \\
\hline Papacharissi and Rubin (2000) & The Internet & $\begin{array}{l}\text { Entertainment, pass time, interpersonal utility, } \\
\text { information seeking, convenience }\end{array}$ \\
\hline Ferguson and Perse (2000) & $\begin{array}{l}\text { TV related web } \\
\text { surfing }\end{array}$ & Entertainment, pass time, relaxation, social information \\
\hline Leung (2001) & $\begin{array}{l}\text { Instant } \\
\text { messaging }\end{array}$ & $\begin{array}{l}\text { Entertainment, affection, relaxation, fashion, inclusion, } \\
\text { sociability, escape }\end{array}$ \\
\hline Stafford and Stafford (2001) & The Internet & $\begin{array}{l}\text { Entertainment, search factor, cognitive factor, news, } \\
\text { unique factors }\end{array}$ \\
\hline Charney and Greenberg (2002) & The Internet & $\begin{array}{l}\text { Division entertainment, peer identity, good feelings, } \\
\text { coolness, keep informed, communication, sights and } \\
\text { sounds, career }\end{array}$ \\
\hline Papacharissi (2002) & $\begin{array}{l}\text { Personal home } \\
\text { pages }\end{array}$ & $\begin{array}{l}\text { Entertainment, pass time, information, self-expression, } \\
\text { professional advancement, communication with friends } \\
\text { and family }\end{array}$ \\
\hline Ko et al. (2005) & The Internet & $\begin{array}{l}\text { Entertainment, social interaction, information, } \\
\text { convenience }\end{array}$ \\
\hline Diddi and LaRose (2006) & Internet news & $\begin{array}{l}\text { Entertainment, escapism, habit, pass time, surveillance, } \\
\text { news quizzes }\end{array}$ \\
\hline Jun and Lee (2007) & Mobile media & $\begin{array}{l}\text { Mobility, convenience, fashion, } \\
\text { entertainment, relaxation, sociality }\end{array}$ \\
\hline Haridakis and Hanson (2009) & $\begin{array}{l}\text { Video-sharing } \\
\text { website }\end{array}$ & $\begin{array}{l}\text { Convenient entertainment, convenient information, } \\
\text { co-viewing, social interaction, }\end{array}$ \\
\hline Zolkepli and Kamarulzaman (2011) & Social media & $\begin{array}{l}\text { Personal integrative needs, social integrative needs, } \\
\text { tension release needs }\end{array}$ \\
\hline
\end{tabular}

In view of the fact that the interactive nature of the web requires high consumer involvement, the application of the $U$ \& G theory to provide an improved understanding of e-consumers were found legitimate in several researches (Eighmey \& McCord, 1998; Korgaonkar \& Wolin, 1999), and many studies have applied this theory to examine consumer experience associated with websites (Chen \& Wells, 1999; Eighmey \& McCord, 1998; Korgaonkar \& Wolin, 1999; Mukherji et al., 1998). The underlying constructs of U\&G used to investigate consumers' site experiences are multiple; but according to the literature, the most important and robust dimensions include entertainment gratification, informativeness gratification and web irritation (Chen \& Wells, 1999; Eighmey \& McCord, 1998; Fenech, 1998; Korgaonkar \& Wolin, 1999; Rubin, 1994; Luo, 2002; Ko et al., 2005).

\subsection{Entertainment Gratification ( $E G$ )}

According to $U$ \& $G$ theory, EG is a major determinant that affects use of a particular media (Luo, 2002). The entertainment construct refers to the extent to which the web media is fun and entertaining to media users (Eighmey \& McCord, 1998). According to McQuail (1983), the value of media entertainment lies in its ability to 
fulfil users' needs for escapism, hedonistic pleasure, aesthetic enjoyment, and/or emotional release. In the work of Kim and Forsythe (2007), it was found that online shoppers have a desire for these entertainment pleasures when shopping online. Sites which are able to provide higher entertainment value was established to have a higher tendency to lead to an advantage for media users and to motivate them to use the media more often (Luo, 2002). This is supported by Stafford and Stafford (2001) and Wolfinbarger and Gilly (2001) as enjoyment, entertainment and human were found to be important reasons for re-visiting a website; in this study, such factors are referred to as 'entertainment gratification'. Notably, the occurrence of site re-visiting will only occur if consumers have favourable attitude towards the site i.e. the site satisfies the user needs for EG (Mukherji et al., 1998). The study of Ducoffe (1995) further evidences that the entertainment value that is provided by the website is positively related to the users' attitude towards the website. A high degree of pleasure and involvement during interaction with computer-based media leads to concurrent subjective perceptions of positive affect and mood of the consumer (Hoffman \& Novak, 1996). The work of Shavitt et al. (1998) further supports this notion as their study concludes that the enjoyment associated with the site play the greatest role in accounting for their overall attitudes toward them. Accordingly, the study proposes that:

H1: Entertainment gratification of online shopping sites will positively influence consumers' attitude towards online shopping.

\subsection{Informativeness Gratification (IG)}

IG is another major determinant that affects use of a particular media under the U\&G theory (Luo, 2002). The informativeness construct refers to the extent to which the web media provides users with resourceful and helpful information to media users (Chen \& Wells, 1999). According to Maddox (1998), the most important reason for people to go online is to gather various kinds of information. Subsequently, Haq (2009) suggests that the quality of information placed on a company's website shows a direct influence on customers' perceptions of the company and the company's product and/or service offerings, and thereby shaping the formation of user attitudes towards the site. This is supported by the work of Bauer and Greyser (1968) as media users consider the media's ability to provide audience information the fundamental reason for accepting the media itself. Similarly, Rotzoll et al. (1989) held that the media's informational role is its major legitimizing function. Siau and Shen (2003) added that web users often demand qualitative features, such as accuracy, timeliness, and usefulness, in the informational content that is projected in websites, and those which are able to fulfil the needs of IG will in turn create favourable attitudes among its audiences (Luo, 2002). This is in line with the findings of Barkhi et al. (2008) as their study suggests that consumers will develop favourable attitudes toward sites that they believe to provide sufficient benefits or attributes toward a solution and negative attitudes toward those that are inadequate. Indeed, past studies have collectively found a substantial and positive relationship between IG and attitude (Chen \& Wells, 1999; Ducoffe, 1995; Maddox, 1998). Hence, it is expected that:

H2: Informativeness gratification of online shopping sites will positively influence consumers' attitude towards online shopping.

\subsection{Web Irritation (WI)}

WI is another major determinant that affects use of a particular media under the $U$ \& G theory (Luo, 2002). The irritation construct refers to the extent to which the web is messy and irritating to media users (Eighmey \& McCord, 1998). According to Gao and Wu (2010), some online vendors unconsciously employ tactics, such as pop-up ads and animated banners, which were intended to attract site visitors but instead induced annoyances among its audiences. Shavitt et al. (1998) argued that the indignity that audiences feel when being addressed by media has a very great influence on their attitude towards the media. When a media employs techniques that annoy, offend, insult or are overly manipulative, consumers are likely to perceive it as unwanted and irritating influence (Ducoffe, 1995). This is also evident in the context of consumer behaviour as criticisms of advertising and marketing schemes aimed at consumers tend to focus on the annoyance and irritation that they cause and the subsequent results of avoidance behaviour (Peters et al., 2007). Further research associated with web media indicated that irritating features, such as unrelated pop-up banners and eye-glaring visuals, often exploit human anxiety, distract consumers' attentions, and dilute human experiences (Ducoffe, 1996). In turn, consumers may feel confused about them and react negatively (Haq, 2009). This is supported by Gao et al. (2004) as consumer feelings of confusion, distraction, and messiness of online shopping sites have been found to often induce irritation. Notably, the irritation arise may lead to a general reduction of media effectiveness and creation of unfavourable attitudes among audiences (Aaker \& Bruzzone, 1985). This is supported by Ducoffe (1995) and Luo (2002) as both studies yield a significant and negative influence of web irritation on consumers' attitude towards subject behaviour. These arguments lead to the following hypothesis: 
H3: Web irritation of online shopping sites will negatively influence consumers' attitude towards online shopping.

\subsection{Relationship between Attitude and Intention}

Attitude has long been identified as the most noteworthy indicator of intention (Suki \& Ramayah, 2010). Attitude toward the behaviour is defined as the individual's positive or negative feelings about performing the behaviour (Fishbein \& Ajzen, 1975). Ajzen and Fishbein (1980) further added that an individual's attitude is determined through an assessment of beliefs regarding the consequences arising from the behaviour and an evaluation of the desirability of these consequences. Many researchers have presented the construct as a mediator of advertising and marketing effects on consumer outcomes (Lutz, 1985). According to Chen and Wells (1999), attitude toward the site is considered as a key determinant of both consumer adoption and usage of the site, and site marketing effectiveness. This is supported by Haley and Baldinger (1991) as the degree to which audiences like an advertisement or marketing campaign is the foremost predictor of sales. In the context of online shopping, the website for an online retailer is the main contact point by which the online retailer and consumers interface in the online shopping process (Ahn et al., 2004). Chen et al. (2002) and Suh and Han (2002) echoed this notion and further emphasised the understanding of user expectations and how they feel about the websites that they use are essential indicators to behavioural intention. In the work of Al-Rafee and Cronan (2006), attitude was found to be the most significant construct in influencing behavioural intention. Notably, the more positive a consumers' attitude towards online shopping, the higher the intention he or she has to engage in online shopping (Ahn et al., 2004). Thus, the study posits that:

H4: Consumers' attitude towards online shopping will positively influence intention to engage in online shopping.

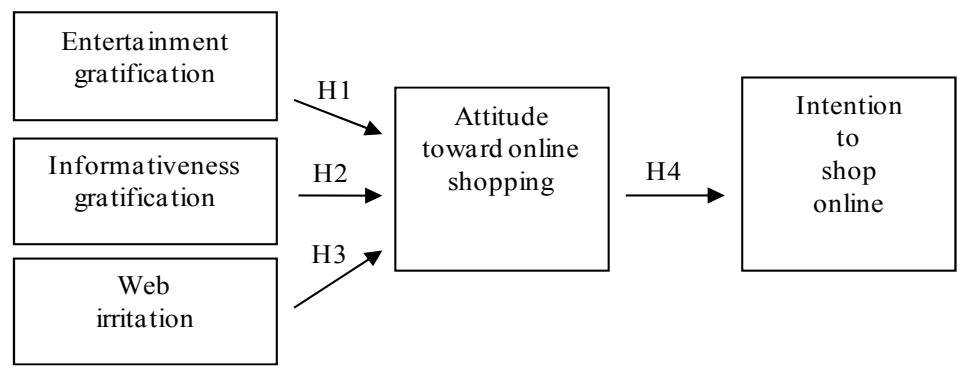

Figure 1. Research framework

\section{Research Methodology and Design}

The current study uses a survey research in order to examine the influence of the uses and gratifications structure on the formation of consumer attitudes and online shopping intentions.

\subsection{Method of Data Collection}

Data in this study was collected through a questionnaire survey. The survey instrument consisted of 32 items (shown in Table 2).

Table 2. Summary of items and sources

\begin{tabular}{llcll}
\hline \multicolumn{1}{c}{ Variables } & \multicolumn{1}{c}{ Research variables } & Number of items & \multicolumn{1}{c}{ Sources } \\
\hline $\begin{array}{l}\text { Socio-demographic } \\
\text { variables }\end{array}$ & $\begin{array}{l}\text { Gender, age, marital status, } \\
\text { income, occupation, highest } \\
\text { academic qualification, race. }\end{array}$ & 7 & $\begin{array}{l}\text { Ramayah et al. (2009); Kim \& Forsythe } \\
(2010) .\end{array}$ \\
$\begin{array}{l}\text { Independent } \\
\text { variables/Dependent } \\
\text { variables }\end{array}$ & $\begin{array}{l}\text { Enfertainment gratification } \\
\text { Informativeness gratification }\end{array}$ & 5 & $\begin{array}{l}\text { Chen et al. (2002); Ducoffe (1996). } \\
\text { Bruner \& Kumar (2005); Ramayah et al. } \\
(2009) .\end{array}$ \\
& $\begin{array}{l}\text { Web irritation } \\
\text { Attitude toward online } \\
\text { shopping } \\
\text { Intention to shop online }\end{array}$ & 5 & $\begin{array}{l}\text { Ducoffe (1996); Korgaonkar \& Wolin (1999). } \\
\text { Ramah et al. (2009); Kim \& Forsythe } \\
\text { Dependent variable }\end{array}$ \\
\hline
\end{tabular}


Items which reflect each variable in the research framework were measured on a five-point Likert scale from (1) 'strong disagree' to (5) 'strongly agree'. Also, respondents were asked socio-demographic questions. Relationally, all questions pertaining to this subject were fixed-alternative questions - respondents were given limited alternative responses and were required to choose the response closest to the respondents' point of view.

\subsection{Sampling Design Technique}

\subsubsection{Target Population}

According to Beal and Dawson (2007), questionnaires are employed when a large group of respondents are easily accessible to answer specific pre-determined marketing propositions. For the current study, a list of questions related to the uses and gratifications constructs and consumer behaviour constructs (i.e. attitude and intention) is generated and distributed to 300 consumers from an unbounded age range in shopping complexes in Klang Valley, Malaysia. The age range was intentionally left unbounded to discover the actual distribution of consumers who are exposed to online shopping based on a random sample. Klang Valley is chosen as it is a satellite town of the Malaysian capital that comprises of both urban and suburban community and hence, making it the most strategic location among the 14 states in the country (Euromonitor, 2011). The survey research is conducted in shopping complexes around Klang Valley. While it may be argued that online shopping sites would be a much better site for the study, the fact that no Malaysian shopping websites allow for the administration of external questionnaires along with the high ambiguity results often projected in online questionnaires would hinder efforts to obtain results which are less-biased and less-error prone. Participation is voluntary and no incentive was offered for any respondent's participation.

\subsubsection{Sampling Method}

The current study collects quantitative data using a survey research from 300 respondents. This sample size is widely regarded as a suitable composition for a study of this nature as existing studies have shown that a sample of approximately 300 respondents is a suitable sample of the population that promotes good reliability and validity (Clarke \& Dunlap, 2008). Data are collected using a mall-intercept survey method through a set of questionnaires. The probability sampling method was used in the current study to obtain a random sample. Simple random sampling was employed to select a sample of shopping malls for questionnaire distribution from a list of shopping malls in Klang Valley, Malaysia. Systematic sampling was used to select the participants for the current study - every $k$ th person that passes the entrance of the mall was selected. A screening question was asked to identify consumers who have a previous experience of online shopping as these consumers are deem to have the experience to evaluate the items measuring the research variables.

\subsection{Questionnaire Items and Sources}

A total of 32 questions subside within the questionnaire distributed to the respondents of the study. The first section of the questionnaire identifies the socio-demographic background of the respondents. The following sections incorporated five-point Likert scale questions relating to EG, EG, WI, attitude and intention. Table 2 presents a summary of items and sources.

\subsection{Outline of Data Processing and Analysis}

First, a descriptive analysis is conducted to supply information pertaining to the demographic profile of the sample. Second, factor analysis and reliability testing is conducted to ordeal the validity and reliability of the questions employed (questions were obtained from an extensive literature search) to measure research variables. Third, a correlation analysis is conducted to test for existence of multi-colinearity. Fourth, multiple regression analyses are conducted to test the relationship between the whole set of independent variables and dependent variables in the research framework. Fifth, unstandardized residuals from the regression analyses are saved and tested for normality using the One-Sample Kolmogorov Smirnov Test. Sixth, hypothesis testing is conducted to determine whether hypotheses proposed based upon a review from existing literature are support or not supported. Seventh, implications of the results from the analyses are discussed and recommendations are presented.

\section{Data Analysis and Findings}

\subsection{Respondent Demographics}

Table 3 presents a summary of respondent socio-demographics profile. 
Table 3. Summary of respondent socio-demographics profile

\begin{tabular}{|c|c|c|c|}
\hline Socio-demographic variables & Description & Frequency & Percent \\
\hline \multirow[t]{2}{*}{ Gender } & Male & 94 & 31.3 \\
\hline & Female & 206 & 68.7 \\
\hline \multirow[t]{5}{*}{ Age } & Below 20 & 22 & 7.3 \\
\hline & 21 to 30 & 169 & 56.3 \\
\hline & 31 to 40 & 93 & 31.0 \\
\hline & 41 to 50 & 10 & 3.2 \\
\hline & 51 and above & 6 & 2.0 \\
\hline \multirow[t]{3}{*}{ Marital status } & Single & 184 & 61.3 \\
\hline & Married & 105 & 35.0 \\
\hline & Divorce & 11 & 3.7 \\
\hline \multirow[t]{6}{*}{ Income } & RM1000 and below & 46 & 15.3 \\
\hline & RM1001 to RM2000 & 15 & 5.0 \\
\hline & RM2001 to RM3000 & 88 & 29.3 \\
\hline & RM3001 to RM4000 & 74 & 24.7 \\
\hline & RM4001 to RM5000 & 36 & 12.0 \\
\hline & RM5000 and above & 41 & 13.7 \\
\hline \multirow[t]{4}{*}{ Occupation } & Student & 50 & 16.7 \\
\hline & Full time employee & 228 & 76.0 \\
\hline & Part time employee & 12 & 4.0 \\
\hline & Unemployed & 10 & 3.3 \\
\hline \multirow[t]{3}{*}{ Highest academic qualification } & High school & 120 & 40.0 \\
\hline & Undergraduate & 157 & 52.3 \\
\hline & Postgraduate & 23 & 7.7 \\
\hline \multirow[t]{3}{*}{ Race } & Malay & 124 & 41.3 \\
\hline & Chinese & 159 & 53.0 \\
\hline & Indian & 17 & 5.7 \\
\hline
\end{tabular}

In the current study, the majority of the respondents who had previously shopped online were females. This contradict the findings of past Internet studies in developed countries (Korgaonkar \& Wolin, 1999; Swinyard \& Smith, 2003) which found that online shoppers tend to be males. This finding, nonetheless, suggests that there is a variation between genders of online shoppers in developed and developing countries as the current finding conformed to the recent finding of Delafrooz et al. (2010) and Hashim et al. (2009) which concludes that most online shoppers in developing countries, such as Malaysia, were females. A similar state of affair can also be observed in relation to age. In particular, the current study found that the majority of online shoppers in Malaysia fall in a combined category of age 30 and below. This suggests that online shoppers are actually younger in age and thereby contradicts findings from studies in several developed countries (such as those of Bhatnagar et al. (2000)). In terms of marital status, most respondents were single $(61.3 \%)$ whereas $35.0 \%$ were married while only $3.7 \%$ of them were divorced. The income levels were not similar across the respondents, but no clear pattern could be found. Most respondents earned between a combined income range of RM2001 to RM4000 $54.0 \%$. Majority of the respondents $(76.0 \%$ ) are working full time while $16.7 \%$ and $4 \%$ are students and working part-time respectively. In terms of highest academic qualification, most respondents have an undergraduate qualification (52.3\%), while $40.0 \%$ have last studied until high school and only $7.7 \%$ hold a postgraduate qualification. In other words, a large majority of respondents had a graduate background. Finally, in terms of race, the Chinese group was the highest contributor of the total respondents $(53.0 \%)$ while the second highest and third highest groups were represented by Malays (41.3\%) and Indians (5.7\%) respectively. These findings are in line with the work of Alam et al. (2008) as these descriptions are somewhat similar with the current population of the Malaysian Internet users. 


\subsection{Factor Analysis and Reliability Testing}

Factor analysis and reliability testing were conducted to ensure that all research constructs are reliable. Factor analysis was initially performed to reduce the complexity of research constructs and to ensure that minimal latent constructs were employed to explain the shared variance of measured constructs used in the questionnaire (Henson \& Roberts, 2006). Subsequently, the computation of Cronbach's alpha was done using a reliability analysis to ensure consistency of the survey data (Wang et al., 2005). According to Coakes et al. (2010), the Cronbach's alpha is based on average correlation of items within the test. A common rule of thumb is that indicators should have a Cronbach's alpha of at least 0.7 to judge the set of items as reliable (Peterson, 1994). The results for these two tests are presented in Table 4.

Table 4. Summary of factor analysis and Cronbach's alpha test

\begin{tabular}{|c|c|c|c|}
\hline Dimension & Item & $\begin{array}{l}\text { Factor } \\
\text { Loading }\end{array}$ & $\begin{array}{l}\text { Cronbach's } \\
\text { Alpha }\end{array}$ \\
\hline \multirow{5}{*}{$\begin{array}{l}\text { Entertainment } \\
\text { gratification }\end{array}$} & I find it entertaining to shop at online retailers. & 0.901 & \multirow[t]{5}{*}{0.930} \\
\hline & I find that online shopping sites are fun to use. & 0.932 & \\
\hline & I feel excited when I shop online. & 0.818 & \\
\hline & $\begin{array}{l}\text { Using online shopping sites to purchase products provide me } \\
\text { with lots of enjoyment. }\end{array}$ & 0.826 & \\
\hline & I have fun when interacting with online shopping sites & 0.795 & \\
\hline \multirow[t]{5}{*}{$\begin{array}{l}\text { Informativeness } \\
\text { gratification }\end{array}$} & $\begin{array}{l}\text { It is important that online shopping sites are able to give me } \\
\text { information that are of interest to me. }\end{array}$ & 0.834 & \multirow[t]{5}{*}{0.963} \\
\hline & $\begin{array}{l}\text { Accurate information in online shopping sites improves my } \\
\text { shopping effectiveness. }\end{array}$ & 0.928 & \\
\hline & $\begin{array}{l}\text { Timely information in online shopping sites improves my } \\
\text { shopping performance. }\end{array}$ & 0.948 & \\
\hline & $\begin{array}{l}\text { Information in online shopping sites that is useful in aiding my } \\
\text { shopping decisions is appreciated. }\end{array}$ & 0.941 & \\
\hline & $\begin{array}{l}\text { Information in online shopping sites that makes it easier for me } \\
\text { to compare product choices when shopping at online retailers is } \\
\text { desirable. }\end{array}$ & 0.931 & \\
\hline \multirow[t]{5}{*}{ Web irritation } & I often feel irritated when shopping online & 0.979 & \multirow[t]{5}{*}{0.973} \\
\hline & I feel that most online shopping sites are confusing & 0.978 & \\
\hline & I find that most online shopping sites are messy & 0.980 & \\
\hline & $\begin{array}{l}\text { I am often irritated by unwanted pop-ups in most online } \\
\text { shopping sites. }\end{array}$ & 0.870 & \\
\hline & I often feel frustrated when shopping at online stores. & 0.969 & \\
\hline \multirow{5}{*}{$\begin{array}{l}\text { Attitude toward } \\
\text { online shopping }\end{array}$} & I am comfortable to shop from online shopping sites. & 0.835 & \multirow[t]{5}{*}{0.921} \\
\hline & I like to purchase what I need from online shopping sites. & 0.834 & \\
\hline & $\begin{array}{l}\text { I like to seek for product information from online shopping } \\
\text { sites. }\end{array}$ & 0.862 & \\
\hline & I feel happy when I do my shopping online. & 0.863 & \\
\hline & I feel shopping online is a good idea. & 0.798 & \\
\hline \multirow[t]{5}{*}{$\begin{array}{l}\text { Intention to shop } \\
\text { online }\end{array}$} & $\begin{array}{l}\text { It is likely that I will continue to purchase products from online } \\
\text { retailers in the future. }\end{array}$ & 0.786 & \multirow[t]{5}{*}{0.933} \\
\hline & $\begin{array}{l}\text { I intend to continue purchase products from the Internet in the } \\
\text { future. }\end{array}$ & 0.808 & \\
\hline & $\begin{array}{l}\text { I would likely visit an online shopping site to shop for my } \\
\text { needs. }\end{array}$ & 0.903 & \\
\hline & I plan to do more of my shopping via online shopping sites. & 0.852 & \\
\hline & $\begin{array}{l}\text { When I need to buy a particular product, I would search for an } \\
\text { online retailer which has the product. }\end{array}$ & 0.951 & \\
\hline
\end{tabular}


Discription: Factors loading ranged from 0.786 to 0.980 , Cronbach's alpha was calculated for each factor, and each was found reliable $(a=0.930,0.963,0.973,0.921$, and 0.933 respectively). These five factors were: EG, IG, WI, attitude toward online shopping, and intention to shop online.

\subsection{Correlation Analysis}

Correlation analysis was performed to examine the relationship between EG, IG, WI, attitude toward online shopping, and intention to shop online. The results support the non-existence of multi-colinearity as all correlation values are below 0.7 .

Table 5. Summary of correlation analysis

\begin{tabular}{|c|c|c|c|c|c|}
\hline & EG & IG & WI & Attitude & Intention \\
\hline EG & 1 & & & & \\
\hline IG & $0.535 * *$ & 1 & & & \\
\hline WI & $-0.527 * *$ & $-0.561 * *$ & 1 & & \\
\hline Attitude & $0.664 * *$ & $0.449 * *$ & $-0.554 * *$ & 1 & \\
\hline Intention & $0.646 * *$ & $0.479 * *$ & $-0.564 * *$ & $0.540 * *$ & 1 \\
\hline
\end{tabular}

**. Correlation is significant at the 0.01 level (2-tailed).

\subsection{Regression Analysis}

Regression analysis is performed to examine the relationship between the whole set of independent variables and dependent variables. Outliers were removed and Figure 2 represents the direction and strength of each independent variable to the dependable variable and it shows that EG, IG and attitude towards online shopping are all positively related at $\mathrm{p}<0.01$ whereas WI is negatively related at $\mathrm{p}<0.01$.

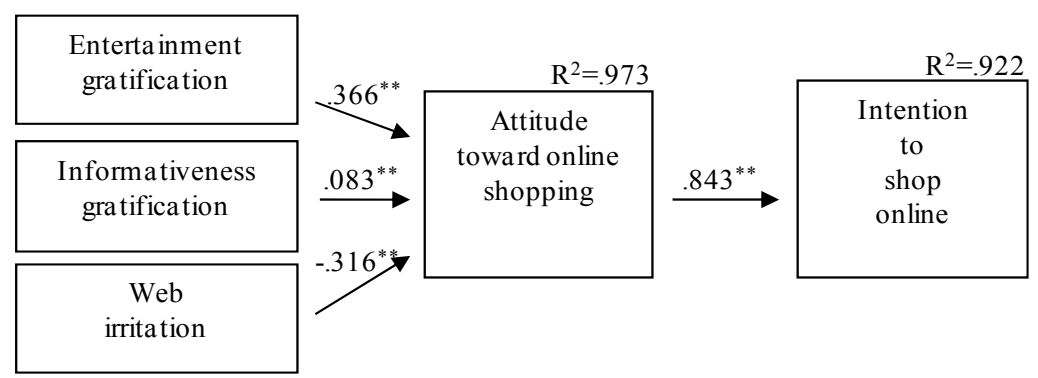

Figure 2. Research framework representing coefficients of each research construct

The general forms of the basic regression test are denoted below as equation one and two whilst the expanded models are written as equation three and four.

Where:

$$
Y=\alpha_{1}+\alpha_{2} X_{1}+\alpha_{3} X_{2}+\alpha_{4} X_{3}+\epsilon
$$

$Y=$ Attitude toward online shopping

$X_{1}=$ Entertainment gratification

$X_{2}=$ Informativeness gratification

$X_{3}=$ Web irritation

$\in=$ Error term

$$
\begin{aligned}
& \hat{Y}=2.723+0.366 X_{1}+0.083 X_{2}-0.316 X_{3} \\
& Y=\alpha_{1}+\alpha_{2} X_{1}+\epsilon
\end{aligned}
$$

Where: 
$Y=$ Intention to shop online

$X_{I}=$ Attitude toward online shopping

$\in=$ Error term

$$
\hat{Y}=0.585+0.843 X_{1}
$$

\subsection{One-Sample Kolmogorov Smirnov Test}

Normality tests were carried out based on the regression analyses. The One-Sample Kolmogorov Smirnov Test for normal distribution showed $\mathrm{p}=0.051$ and $\mathrm{p}=0.061$, all which are greater than $\mathrm{p}>0.05$, and hence, a normal distribution can be assumed.

\subsection{Hypothesis Testing}

Hypothesis testing is carried out to determine whether hypotheses proposed based upon a review from existing literature are supported or not supported. Table 6 projects the results from the testing of hypotheses. All four proposed hypotheses (i.e. H1-H4) that emerged from the literature review are supported based on the results from the multiple regression analyses.

Table 6. Summary of hypothesis testing

\begin{tabular}{ll}
\hline Hypotheses & Supported/Not Supported \\
\hline H1: Entertainment gratification of online shopping sites will positively influence & Supported \\
consumers' attitude towards online shopping. & \\
H2: Informativeness gratification of online shopping sites will positively influence & Supported \\
$\begin{array}{l}\text { consumers' attitude towards online shopping. } \\
\text { H3: Web irritation of online shopping sites will negatively influence consumers' attitude } \\
\text { towards online shopping. }\end{array}$ & Supported \\
$\begin{array}{l}\text { H4: Consumers' attitude towards online shopping will positively influence intention to } \\
\text { engage in online shopping. }\end{array}$ & Supported \\
\hline
\end{tabular}

\section{Implications and Recommendations}

The first hypothesis posited that EG will have a positive effect on consumers' attitude towards online shopping. The study revealed a significant result $(\beta=0.366 ; p=0.000)$. Thus, $\mathrm{H} 1$ is supported. This implies that the entertainment facilitated by technological interfaces and tools on online shopping sites are imperative in predicting the online shopper's attitude towards online shopping. The study's contention is that consumers would develop favourable attitudes toward online shopping if online shopping sites are able to provide gratifying entertainment to its audiences. This result is analogous to the work of Ducoffe (1995) and Shavitt et al. (1998) concluding that EG is a major determinant of attitude towards behaviour. Given this scenario, online retailers are recommended to make shopping at the digital marketplace an entertaining activity. In particular, online shopping sites should be designed in a way that makes it fun to use and provide lots of enjoyment to its visitors and potential customers. The facilitation of interaction between site audiences and online shopping sites is strongly encouraged as Liu and Shrum (2002) suggests that higher levels of interactivity have the potential to generate more user involvement which making online shopping sites fun to use. Interactive rich online shopping sites can be created using advance tools of visualization technologies, such as Flash and Java, thereby enabling the creation of a wide array of entertainment gratifying content. In addition, entertaining games in combination with sales messages can encourage dialogs with customers and project product images. Indeed, online advertising and marketing efforts that is enriched with entertaining elements achieves a more positive evaluation by audiences and leads to higher intent to revisit the homepage than sites without entertainment features (Raney et al., 2003).

Further investigation of study was performed on the second proposed hypothesis on whether there is significant relationship between IG and attitude towards online shopping. Findings in Figure 2 confirmed that IG $(\beta=0.083$; $\mathrm{p}=0.000)$ is significantly related to attitude towards online shopping. Hence, $\mathrm{H} 2$ is verified. The positive attitude towards online shopping is due to reasons that consumers perceive that online shopping provides information that are able to gratify them. To consumers, the degree to which the online shopping site is informatively gratifying strongly influences their attitude. If online shopping sites are able to fulfil their informational role, then consumers form positive attitudes and strong intentions to shop online. They find it desirable and appreciate online shopping sites with accurate, timely, and quality information that is useful and 
enhance their shopping decisions, performance and effectiveness. This is in line with the findings by Barkhi et al. (2008), Bauer and Greyser (1968), Chen and Wells (1999), Ducoffe (1995), Haq (2009), Luo (2002), Maddox (1998), and Siau and Shen (2003). Given this orientation, online retailers are recommended to ensure that quality information is placed on their online shopping sites. The information should be useful to consumers and enhance their shopping decisions, performance and effectiveness. This is supported by Stewart and Pavlou (2002) whose work had pointed out the importance of interactive media, such as the sites on the Internet, as an information broker that allows customers to acquire real-time information that was previously not available. Notably, online retailers should ensure that the uploaded information is relevant, accurate and constantly updated to ensure timeliness. The arrangement and placement of information is also crucial as it has a direct influence on customers' perceptions of the company and the company's product and/or service offerings, and thereby shaping the formation of consumers' attitude towards the site (Haq, 2009). In any event, consumers want the content of online shopping sites to be tailored to their interest. As such, interesting facts and figures could be incorporated as a way to cultivate informativeness gratification. This may be perceived as an added value that the consumer may even be willing to pay for in some cases (Stewart \& Pavlou, 2002).

Next, the third hypothesis exhibited a significant negative relationship between WI and consumer attitude towards online shopping ( $\beta=-0.316 ; \mathrm{p}=0.009$ ). Its $p$-value is $<0.05$, posited that $\mathrm{H} 3$ is supported by the data. This suggests that the confusion, frustration and messiness on online shopping sites have a significant influence on consumers' irritation level for online shopping. To consumers, the degree to which the online shopping site is perceived to be irritating strongly influences their attitude towards online shopping. If online shopping sites are irritating, then consumers form negative attitudes toward online shopping. The strong correlation coefficient indicates that the influence of irritation is as strong as the influence of the entertainment and informativeness construct. This result validates the postulation in the research of Aaker and Bruzzone (1985), Ducoffe (1995), Eighmey and McCord (1998) and Luo (2002) that suggests WI does have a negative influence on consumer attitudes. The work of Luo (2002) noted that by irritating web users, online businesses will find it notoriously difficult to get consumers back to their websites in the future. Notably, irritation is a phenomenon that is similar to reactance, that is, consumers tend to refuse visiting a site if they have the feeling that the site is too intrusive (Kroeber-Riel \& Weinberg, 2003). As such, entrepreneurs and marketers of online shopping sites are recommended to avoid showing interrupting ads such as pop-ups. Nonetheless, the perception of intrusiveness can, however, decrease if the ads are relevant to the target audiences and if they provide value to the recipient (Edwards et al., 2002). Several others instances also merits a seizure, which includes inducing overly flashing and big size graphics, messy presentation of information, and even deceptive content on the site to avoid confusing, frustrating, and irritating site visitors. This is supported by Wilson (2010) as online retailers would want site visitors to actually stay long enough to make a purchase or enjoy some of the content that their online support developers have worked so hard to produce and thus it would not be wise to bombard them with such obnoxious presentations.

Finally, the fourth hypothesis proposed that consumers' attitude towards online shopping will have a positive influence on their online shopping intentions. The findings of this study concludes that consumers' attitude towards online shopping does have a positive significant relationship with their intention to shop online $(\beta=$ $0.843 ; \mathrm{p}=0.000)$. Its $p$-value is $<0.05$ and its strong correlation coefficient suggests that $\mathrm{H} 4$ is strongly supported. This study contends that consumers who have positive attitudes will have a strong likelihood to shop from online shopping sites. Furthermore, consumers who have favourable attitudes towards online shopping are also more likely to search and plan for shopping purchases via the digital marketplace. Thus, the significant role of attitudes in shaping behavioural intention has been visible when a relationship between attitude and behavioural intention is studied. In order for online retailers to foster desirable positive attitudes and make target customers feel that shopping online is a good idea, it is recommended that crafted advertising and marketing strategies should focus on creating an enjoyable and comfortable environment in the online retail stores. As noted earlier, entrepreneurs and marketers of online shopping sites are strongly encouraged to focus efforts towards the promotion of EG and IG. Efforts towards the avoidance of WI are equally important as shown by the strong correlation coefficient for WI under the current study.

\section{Limitations and Future Research Directions}

Online consumer behaviour is a broad area of study. The researchers acknowledge that the current study has only investigated a modest part of this area. Thus, future research directions are presented based on the following limitations of the current study.

First, this study has only measured the influence of EG, IG and WI on consumers' attitudes in a general overview on consumers' attitudes towards online shopping. A natural progression for future research from the 
current study is to further examine these constructs from the U\&G strucuture in light of the different categories of products and services that are intended to be purchased by consumers through the online shopping channel. Thus, more categorical-focused recommendations can be presented in line with the quantity of effect that is involved in each construct in the researched $U \& G$ structure.

Second, this study did not investigate for the antecedents of the constructs in the U\&G structure. As the current study is quantitative in nature, a qualitative research using interpersonal individual interviews and focus group discussions would be fruitful to identify the antecedents of EG, IG and WI. Such an investigation will provide valuable insights into more specific components of an online shopping site that consumers regard as providing EG and IG and those that is negatively associated to WI.

Lastly, this study is limited to the sampling population. Due to concerns that sampling from the general Malaysian population may yield a large portion of unusable data for the lack of experience with electronic commerce sites, the researchers chose to sample a population (i.e. Klang Valley, Malaysia) that is regarded as the satellite town of the Malaysian capital as it contains a high percentage of Internet users. Even during the sampling process, many individuals have been rejected into the sample as they did not meet the sampling criteria of having some prior experience with online shopping sites. Hence, it is suggested that future research can be replicated in other Asian countries or other populations to see if the proposed relationships still hold and to identify cultural differences that may impact on the formation of consumer attitudes and intention towards online shopping.

\section{Conclusion}

This study has contributed to the evolving body of literature on Internet U\&G, particularly in a more context-specific scenario (in this case, online shopping) and also in developing countries like Malaysia. In particular, the relationship between EG, IG, WI, attitude towards online shopping, and consumers' intention to shop online was researched. Findings from the study suggest that consumers' intention to shop online is determined by their attitude towards online shopping. Furthermore, the results highlighted the importance of facilitating EG and IG in online shopping sites towards consumers' attitude towards online shopping in terms of how entertaining and informative online shopping sites are in creating a favourable shopping environment. Nonetheless, WI was also found to be of equal importance in influencing the formation of consumers' attitude towards online shopping, but in a negative manner. Notably, the study has shown what the implications of such an analysis are to entrepreneurs, marketers and website system developers of online shopping sites.

As a whole, findings from the current study provide a significant contribution in understanding the influence of the U\&G structure on consumer behaviour towards online shopping. Thoughts on the factors identified should propel increase adoption and attractiveness of online shopping. The results from the study suggests consumers' need to be provided with a online shopping experience that is entertaining, informative and free from irritation. Future research can further evaluate and analyse the U\&G structure from a larger perspective by examining the structure from different product and service categories, identifying the antecedents of EG, IG and WI, the legitimacy of proposed relationships and cultural differences on the influence of the U\&G structure on consumer behaviour.

\section{References}

Aaker, A. D., Kumar, V., \& Day, G. S. (1995). Marketing Research (5 ${ }^{\text {th }}$ ed.). New York, John Wiley \& Sons.

Ahn, T., Ryu, S., \& Han, I. (2004). The impact of the online \& offline features on the user acceptance of Internet shopping malls. Electronic Commerce Research \& Applications, 3(4), 405-420. http://dx.doi.org/10.1016/j.elerap.2004.05.001

Ajzen, I., \& Fishbein, M. (1980). Understanding attitudes \& predicting social behaviour. Prentice-Hall, Englewood Cliffs, New Jersey.

Alam, S. S., Bakar, Z., Ismail, H., \& Ahsan, M. N. (2008). Young consumers online shopping: an empirical study. Journal of Internet Business, 1(5), 81-98.

Al-Rafee, S., \& Cronan, T. P. (2006). Digital piracy: factors that influence attitude toward behaviour. Journal of Business Ethics, 63(3), 237-259. http://dx.doi.org/10.1007/s10551-005-1902-9

Beal, D. J., \& Dawson, J. F. (2007). On the use of Likert scales in multilevel data: influence on aggregate variables. Organizational Research Methods, 10(4), 657-672. http://dx.doi.org/10.1177/1094428106295492

Berthon, P., Pitt, L., \& Watson, R. (1996). The world wide web as an advertising medium: toward an understanding of conversion efficiency. Journal of Advertising Research, 36(1), 432-445. 
Bhatnagar, A., Misra, S., \& Rao, H. R. (2000). On risk, convenience, \& Internet shopping behaviour: why some consumers are online shoppers while others are not. Communications of the ACM, 43(11), 98-105. http://dx.doi.org/10.1145/353360.353371

Broekhuizen, T., \& Huizingh, E. K. R. E. (2009). Online purchase determinants: is their effect moderated by direct experience? Management Research News, 32(5), 440-457. http://dx.doi.org/10.1108/01409170910952949

Bruner, G. C. II., \& Kumar, A. (2005). Explaining consumer acceptance of handheld Internet devices. Journal of Business Research, 58(5), 553-558. http://dx.doi.org/10.1016/j.jbusres.2003.08.002

Central Intelligence Agency. (2011). The world fact book. Retrieved from https://www.cia.gov/cia/publications/factbook

Charney, T., \& Greenberg, B. S. (2002). Uses \& Gratifications of the Internet in Lin, C. A. \& Atkin, D.. Communication Technology \& Society: Audience, Adoption \& Uses, Hampton, Cresskill, New Jersey.

Chen, L., Gillenson, M. L., \& Sherrell, D. L. (2002). Enticing online consumers: an extended technology $\begin{array}{lllll}\text { acceptance perspective. Information \& } & \text { Management, }\end{array}$ http://dx.doi.org/10.1016/S0378-7206(01)00127-6

Chen, Q., \& Wells, W. D. (1999). Attitude toward the site. Journal of Advertising Research, 39(5), 27-37.

Chiu, C. M., Chang, C. C., Cheng, H. L., \& Fang, Y. H. (2009). Determinants of customer repurchase intention in online shopping. Online Information Review, 33(4), 761-784. http://dx.doi.org/10.1108/14684520910985710

Clarke, S., \& Dunlap, G. (2008). A descriptive analysis of intervention research published in the Journal of Positive Behaviour Interventions: 1999 through 2005. Journal of Positive Behaviour Interventions, 10(1), 67-71. http://dx.doi.org/10.1177/1098300707311810

Coakes, S. J., Steed, L., \& Ong, C. (2010). SPSS: analysis without anguish: version 17 for Windows. Australia, John Wiley \& Sons.

Cook, D. L., \& Coupey, E. (1998). Consumer behaviour \& unresolved regulatory issues in electronic marketing. Journal of Business Research, 41(July), 213-238.

Delafrooz, N., Paim, L. H., \& Khatibi, A. (2010). Understanding consumers Internet purchase intention in Malaysia. African Journal of Business Management, 5(3), 2837-2846.

Diddi, A., \& Larose, R. (2006). Getting hooked on news: uses \& gratifications \& the formation of news habits among college studies in an Internet environment. Journal of Broadcasting \& Electronic Media, 50(2), 193-210. http://dx.doi.org/10.1207/s15506878jobem5002_2

Ducoffe, R. H. (1995). How consumers assess the value of advertising. Journal of Current Issues \& Research in Advertising, 17(1), 1-18.

Ducoffe, R. H. (1996). Advertising value \& advertising on the web. Journal of Advertising Research, 36(5), 21-36.

Edwards, S. M., Li, H., \& Lee, J. H. (2002). Forced exposure \& psychological reactance: antecedents \& consequences of the perceived intrusiveness of pop-up ads. Journal of Advertising, 31(3), 83-95.

Eighmey, J., \& McCord, M. (1998). Adding value in the information age: uses \& gratifications of sites on the world wide web. Journal of Business Research, 41(3), 187-194. http://dx.doi.org/10.1016/S0148-2963(97)00061-1

Ellison, S. K. W. (2010). Need for more updated \& empirical research on online shopping. Retrieved from http://www.infotechonline.sg/articles/9/11/198989.htm

Euromonitor. (2011). Consumer lifestyles in Malaysia. Retrieved from Euromonitor International database.

Fenech, T. (1998). Using perceived ease of use \& perceived usefulness to predict acceptance of the world wide web. Computer Networks \& ISDN Systems, 30(1-7), 629-631.

Ferguson, D. A., \& Perse, E. M. (2000). The world wide web as a functional alternative to television. Journal of Broadcasting \& Electronic Media, 44(2), 155-174. http://dx.doi.org/10.1207/s15506878jobem4402_1

Fishbein, M., \& Ajzen, I. (1975). Belief, attitude, intention \& behaviour: an introduction to theory \& research. Addison-Wesley, California. 
Gao, Y., Koufaris, M., \& Ducoffe, R. (2004). An experimental study of the effects of promotional techniques in Web-based commerce. Journal of Electronic Commerce in Organizations, 2(3), 1-20. http://dx.doi.org/10.4018/jeco.2004070101

Gao, Y., \& Wu, X. (2010). A cognitive model of trust in e-commerce: evidence from a field study in China. The Journal of Applied Business Research, 26(1), 37-44.

Grover, V., \& Pradipkumar, R. (1999). Six myths of information \& markets: information technology networks, electronic commerce, \& the battle for consumer surplus. MIS Quarterly, 23(4), 465-495. http://dx.doi.org/10.2307/249486

Haley, R. I., \& Baldinger, A. L. (1991). The ARF copy research validity project. Journal of Advertising Research, 31(2), 11-32.

Hanjun, K. (2000). Internet uses \& gratifications: understanding motivations for using the Internet. Annual Meeting of the Associate for Education in Journalism \& Mass Communication, Washington, USA.

Haq, Z. U. (2009). E-mail advertising: a study of consumer attitude toward e-mail advertising among Indian users. Journal of Retail \& Leisure Property, 8(3), 207-223. http://dx.doi.org/10.1057/rlp.2009.10

Haridakis, P., \& Hanson, G. (2009). Social interaction \& co-viewing with YouTube: blending mass communication reception \& social connection. Journal of Broadcasting \& Electronic Media, 53(2), 317-335. http://dx.doi.org/10.1080/08838150902908270

Hashim, A., Ghani, E. K., \& Said, J. (2009). Does consumers demographic profile influence online shopping?: an examination using Fishbein's theory. Canadian Social Science, 5(6), 19-31.

Henson, R. K., \& Roberts, J. K. (2006). Use of exploratory factor analysis in published research. Educational \& Psychological Measurement, 66(3), 393-416. http://dx.doi.org/10.1177/0013164405282485

Hoffman, D. L., \& Novak, T. P. (1996). Marketing in hypermedia computer-mediated environments: conceptual foundations. Journal of Marketing, 60(3), 50-68. http://dx.doi.org/10.2307/1251841

Internet World Stats. (2011). Internet usage \& world population statistics. Retrieved from

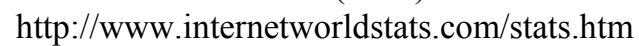

Jere, M. G., \& Davis, S. V. (2011). An application of uses \& gratifications theory to compare consumer motivations for magazine \& Internet usage among South African women's magazine readers. South African Business Review, 15(1), 1-27.

Jun, J. W., \& Lee, S. (2007). Mobile media use \& its impact on consumer attitudes towards mobile advertising. International Journal of Mobile Marketing, 2(1), 50-59.

Katz, E. (1959). Mass communication research \& the study of culture. Studies in Public Communication, 2(1), $1-6$.

Katz, E., Blumler, J. G., \& Gurevitch, M. (1974). Utilization of mass communication by the individual. The Uses of Mass Communications: Current Perspectives on Gratifications Research, 19-32.

Kaye, B. K. (1998). Uses \& gratifications of the world wide web: from couch potato to web potato. The New Jersey Journal of Communication, 6(1), 21-40. http://dx.doi.org/10.1080/15456879809367333

Kaye, B. K., \& Johnson, T. J. (2001). A web for all reasons: uses \& gratifications of Internet resources for political information. Association for Education in Journalism \& Mass Communication Conference, Washington, USA.

Kim, J., \& Forsythe, S. (2007). Hedonic usage of product virtualization technologies in online apparel shopping. International Journal of Retail \& Distribution Management, 35(6), 502-514. http://dx.doi.org/10.1108/09590550710750368

Kim, J., \& Forsythe, S. (2010). Factors affecting adoption of product virtualization technology for online consumer electronics shopping. International Journal of Retailing \& Distribution Management, 38(3), 190-204. http://dx.doi.org/10.1108/09590551011027122

Klapper, J. T. (1960). The effects of mass communication. Illinois Free, Press.

Ko, H., Cho, C. H., \& Roberts, M. S. (2005). Internet uses \& gratifications: a structural equation model of interactive advertising. Journal of Advertising, 34(2), 57-70. 
Korgaonkar, P. K., \& Wolin, L. D. (1999). A multivariate analysis of web usage. Journal of Advertising Research, 39(2), 53-68.

Kroeber-Riel, W., \& Weinberg, P. (2003). Konsumentenverhalten. Verlag Franz VahlenMuenchen, Munich.

Leung, L. (2001). College student motives for chatting on ICQ. New Media \& Society, 3(4), 483-500. http://dx.doi.org/10.1177/14614440122226209

Liu, Y., \& Shrum, L. J. (2002). What is interactivity \& is it always such a good thing? Implications of definition, person, \& situation for the influence of interactivity on advertising effectiveness. Journal of Advertising, 31(4), 53-66.

Luo, X. (2002). Uses \& gratification theory \& e-consumer behaviours: a structural equation modelling study. Journal of Interactive Advertising, 2(2), 34-41.

Lutz, R. J. (1985). Affective \& cognitive antecedents of attitude toward the ad: a conceptual framework. Psychological Process \& Advertising Effects: Theory, Research \& Application, Lawrence Erlbaum Associates, Hillsdale, New Jersey, 45-63.

Maignan, I., \& Lukas, B. A. (1997). The nature \& social uses of the Internet: a qualitative investigation. Journal of Consumer Affairs, 31(2), 346-371. http://dx.doi.org/10.1111/j.1745-6606.1997.tb00395.x

McQuail, D. (1983). Mass communication theory. Sage, London.

Morris, M., \& Ogan, C. (1996) The Internet as a mass medium. Journal of Communication, 46(1), 39-50. http://dx.doi.org/10.1111/j.1460-2466.1996.tb01460.x

Mukherji, J., Mukherji, A., \& Nicovich, S. (1998). Understanding dependency \& use of the Internet: a uses \& gratifications perspective. American Marketing Association, Boston.

Novak, T. P., Hoffman, D. L., \& Yung, Y. (2000). Measuring the customer experience in online environments: a $\begin{array}{lllll}\text { structural modelling } & \text { approach, }\end{array}$ http://dx.doi.org/10.1287/mksc.19.1.22.15184

OKeefe, G. J., \& Sulanowski, B. K. (1995). More than just talk: uses, gratifications, \& the telephone. Journalism \& Mass Communications Quarterly, 72(4), 922-933.

Palmer, J. W., \& Griffith, D. A. (1998). An emerging model of website design for marketing. Communications of the ACM, 41(3), 44-51. http://dx.doi.org/10.1145/272287.272296

Papacharissi, Z., \& Rubin, A. M. (2000). Predictors of Internet use. Journal of Broadcasting \& Electronic Media, 44(2), 175-196. http://dx.doi.org/10.1207/s15506878jobem4402_2

Payne, G., Severn, J. H., \& Dozier, D. (1988). Uses \& gratifications motives as indicators of magazine readership. Journalism \& Mass Communications Quarterly, 65(4), 909-913. http://dx.doi.org/10.1177/107769908806500411

Peters, C., Amato, C. H., \& Hollenback, C. R. (2007). An exploratory investigation of consumers perceptions of $\begin{array}{lllll}\text { wireless advertising. } & \text { Journal of }\end{array}$ http://dx.doi.org/10.2753/JOA0091-3367360410

Peterson, R. A. (1994). A meta-analysis of Cronbach's coefficient alpha. Journal of Consumer Research, 21(2), 381-391. http://dx.doi.org/10.1086/209405

Raney, A. A., Arpan, L. M., Padhupati, K., \& Brill, D. A. (2003). At the movies, on the web: an investigation of the effects of entertaining \& interactive web content on site \& br\& evaluations. Journal of Interactive Marketing, 17(4), 38-53. http://dx.doi.org/10.1002/dir.10064

Rafaeli, S., \& Sudweeks, F. (1997). Networked interactivity. Journal of Computer Mediated Communication, 2(4). Retrieved from http://jcmc.indiana.edu/vol2/issue4/rafaeli.sudweeks.html

Ramayah, T., Rouibah, K., Gopi, M., \& Rangel, G. J. (2009). A decomposed theory of reasoned action to explain intention to use Internet stock trading among Malaysian investors. Computers in Human Behaviour, 25(6), 1222-1230. http://dx.doi.org/10.1016/j.chb.2009.06.007

Rayburn, J. D. (1996). Uses \& gratifications. An Integrated Approach to Communication Theory \& Research, Lawrence Erlbaum Associates, Mahwah, New Jersey, 145-163.

Rosenkrans, G. (2009). The creativeness \& effectiveness of online interactive rich media advertising. Journal of Interactive Advertising, 9(2), 18-31. 
Roy, S. K. (2008). Determining uses \& gratifications for Indian internet users. Case Studies in Business, Industry \& Government Statistics, 2(2), 78-91.

Rubin, A. M. (1983). Television uses \& gratifications: the interactions of viewing patterns \& motivations. Journal of Broadcasting, 27(1), 37-51. http://dx.doi.org/10.1080/08838158309386471

Rubin, A. M. (1994). An examination of television viewing motives. Journal of Communication, 8(3), 141-165.

Ruggiero, T. E. (2000). Uses \& gratifications theory in the $21^{\text {st }}$ century. Mass Communication \& Society, 3(1), 3-37. http://dx.doi.org/10.1207/S15327825MCS0301_02

Siekpe, J. S., \& Kamssu, A. A. (2005). The effect of culture \& uses \& gratifications in online shopping. Southwest Decision Sciences Institute 2005: Proceedings of the $36^{\text {th }}$ Southwest Decision Sciences Institute Annual Conference, Southwest DSI, Dallas, USA, 370-378.

Shavitt, S., Lowrey, P., \& Haefner, J. (1998). Public attitudes towards advertising: more favourable than you might think. Journal of Advertising Research, 38(4), 7-22.

Stafford, T. F., \& Stafford, M. R. (2001). Identifying motivations for the use of commercial websites. Information Resources Management Journal, 14(1), 22-30. http://dx.doi.org/10.4018/irmj.2001010103

Stewart, D. V., \& Pavlou, P. A. (2002). From consumer response to active consumer: measuring the effectiveness of interactive media. Journal of the Academy of Marketing Science, 30(4), 376-396. http://dx.doi.org/10.1177/009207002236912

Suh, B., \& Han, I. (2002). Effect of trust on customer acceptance of Internet banking. Electronic Commerce \& Applications, 1(3), 247-263.

Suki, N. M., \& Ramayah, T. (2010). User acceptance of the e-government services in Malaysia: structural equation modelling approach. Interdisciplinary Journal of Information, Knowledge \& Management, 5(1), 395-413.

Swinyard, W. R., \& Smith, S. M. (2003). Why people (don't) shop online: a lifestyle study of the Internet consumer. Psychology \& Marketing, 20(7), 567-597. http://dx.doi.org/10.1002/mar.10087

Wang, F., Zhang, H., Zhang, H., \& Ouyang, M. (2005). Purchasing pirated software: an initial examination of Chinese consumers. The Journal of Consumer Marketing, 22(6), 2340-2351. http://dx.doi.org/10.1108/07363760510623939

Weinberg, B. D. (2000). Don't keep your Internet customers waiting too long at the (virtual) front door. Journal $\begin{array}{llll}\text { of Interactive } & \text { Marketing, } & \text { 723-743. }\end{array}$ http://dx.doi.org/10.1002/(SICI)1520-6653(200024)14:1<30::AID-DIR3>3.0.CO;2-M

Wilson, J. (2010). The Importance of a User Friendly Website. Retrieved from $\mathrm{http}: / /$ suite101.com/content/the-importance-of-a-user-friendly-website-a291164

Wolfinbarger, M., \& Gilly, M. C. (2001). Shopping online for freedom, control \& fun. California Management Review, 43(2), 39-51.

Zolkepli, I. A., \& Kamalrulzaman, Y. (2011). Understanding social media adoption: the role of perceived media needs \& technology characteristics. Asia-Pacific Business Research Conference Proceedings, Malaysia, 1-12. 